\title{
An investigation of e-marketing and its effect on the consumer buying decision during COVID-19 pandemic in Aceh Province, Indonesia: A mediating role of perceived risk
}

\author{
Muhammad Adama, Mahdani Ibrahima ${ }^{a}$, Sofyan Idris ${ }^{a}$, Jumadil Saputra ${ }^{\mathrm{b}}$ and Teuku Roli Ilham- \\ syah Putra ${ }^{a}$
}

${ }^{a}$ Faculty of Economics and Business, Universitas Syiah Kuala, Darussalam, Syiah Kuala, Banda Aceh, Aceh 23111, Indonesia ${ }^{b}$ Faculty of Business, Economics and Social Development, Universiti Malaysia Terengganu, 21030 Kuala Nerus, Terengganu, Malaysia

\section{H R O N I C L E}

\section{Article history:}

Received: June 18, 2021

Received in revised format: July

29, 2021

Accepted: September 25, 2021

Available online: September 25, 2021

Keywords:

e-marketing

Perceived usefulness

Perceived ease of use

Perceived risk

Consumer buying decision

\section{A B S T R A C T}

Today, Coronavirus is a pandemic that has spread worldwide and causes many problems, including socio economic problems in society. Therefore, e-marketing has an essential function in acquiring new customers, generating leads, and generating revenue for your business by reaching customers interested in your products and services. A digital platform such as web marketing is online marketing to prospective leads and high-value consumers. Thus, the present study examined the usage of e-marketing as a model for buying decisions moderated by perceived risk during the covid-19 pandemic in Aceh Province, Indonesia. This quantitative study involved 325 respondents and was collected through a survey by filling out the questionnaires. Also, e-marketing is measured by perceived usefulness, perceived ease of use as exogenous variables. Therefore, perceived risk is a mediating variable, and the consumer buying decision is an endogenous variable. The data were analyzed using Structural Equation Modelling - Analysis of Moments Structure (SEM-AMOS). The results showed that e-marketing (perceived usefulness and ease of use) positively and significantly affects consumer buying decisions. This study also applied the Sobel test and indicated that perceived risk mediates perceived usefulness and ease toward consumer buying decisions. In conclusion, this study has successfully examined the relationship between e-marketing via perceived usefulness and perceived ease of use. Also, it proves that perceived risk plays a mediating role (partial mediator) in the relationship of perceived usefulness and ease of use on consumer buying decisions. This tested model has become a formulation, especially in marketing science, where it turns out that during the covid19 pandemic, the buying decision model in the marketplace is a function of the perceived usefulness and perceived ease of use of consumers towards the marketplace, as well as the perceived risk of the marketplace as a partial mediator. So that marketplace manufacturers can drive consumer buying decisions by consumers by creating a strengthening of perceived usefulness and perceived ease of use for consumers, thereby affecting consumers' perceived risk and impacting their buying decisions.

\section{Introduction}

Coronavirus is a pandemic that has spread worldwide and creates various problems such as social, economic, and increased mortality in society. This virus spreads very fast; generally, the symptoms felt are fever, fatigue, and dry cough. Symptoms that are initially felt are usually mild and begin to improve gradually. However, the government revealed that the covid-19 symptoms were positive and required 14 days of incubation. As a result, the number of confirmed coronavirus cases worldwide

* Corresponding author.

E-mail address: mahdani@unsyiah.ac.id (M. Ibrahim)

(C) 2022 by the authors; licensee Growing Science, Canada. doi: $10.5267 /$ j.ijdns.2021.9.016 
is 39,196,248, with a death toll of 1,101,298 (CFR 2.8\%). What's more, this Coronavirus has also infected 216 countries with 179 local transmission countries (Kemenkes Republik Indonesia, 2020). Table 1 shows the countries with the highest confirmed cases.

Table 1

Countries with the Highest Confirmed Cases

\begin{tabular}{|c|c|c|c|}
\hline Country & Cases & Death & Healed \\
\hline United States & $8,145,010$ & 221,769 & $5,266,301$ \\
\hline India & $7,305,070$ & 111,311 & $5,266,301$ \\
\hline Brazil & $5,140,863$ & 151,747 & $4,568,813$ \\
\hline Russia & $1,340,409$ & 151,747 & $1,039,705$ \\
\hline Spanish & 937,311 & 903,898 & 33,413 \\
\hline Argentina & 931,967 & 24,921 & 751,146 \\
\hline Colombia & 930,159 & 28,306 & 816,667 \\
\hline Peru & 853,974 & 33,419 & 753,959 \\
\hline Mexico & 825,340 & 84,420 & 601,571 \\
\hline France & 779,063 & 33,037 & 103,413 \\
\hline
\end{tabular}

Source: Kompas.com - 15/10/2020

Indonesia is one of the countries with a very high level of causation, ranked 23rd globally. The number of confirmed cases of covid-19 in Indonesia reached 357,762 people from the number of specimens examined as many as 2,505,898 people. While those who recovered (positive for covid-19) were 281,592 people, and those who died (positive for covid-19) were 12,431 (CFR 3.5\%). With this number, Indonesia is among the countries with the highest confirmed cases of Covid-19 in the ASEAN region (Kemenkes Republik Indonesia, 18 October 2020). With the emergence of covid-19, the Indonesian government has emphasized that people should not carry out activities outside their homes to avoid the increasing spread of covid-19. In some areas with the highest spread rates, the government has implemented social distancing rules or Large-Scale Social Restrictions (PSBB). Implementing physical distancing/social distancing and an appeal to self-isolate or what is known as "stay at home" causes limited space for movement and minimal mobility (Lestari, 2020). Meanwhile, for cases of the spread of covid-19 in Aceh Province, Indonesia, the number of confirmed cases is 6,436 people, with a death rate of 226 people, and the number of patients who have recovered (positive for covid-19) is 4,318. For now, the Indonesian people have started to obey and carry out the rules given by the government, although there are still many people who have not obeyed them. However, from this policy and the spread of this virus, problems have arisen from various social circles, including the upper, middle, and lower classes. And, of course, the lower classes who feel the impact is very significant. The reason is that they have difficulty making a living and getting covid-19 prevention tools such as hand sanitizers and masks so that they are among those who are easily infected with the virus, causing death. The government is also trying its best to treat covid-19 patients to the maximum and provide prevention tools to the lower classes. In addition, the current condition of Indonesia, which is a country with a demographic bonus, which should be in a situation of building a tremendous economic power, has had to experience delays in economic progress due to this virus outbreak. In other words, the current condition of Indonesia's economy is disrupted. In addition, with the implementation of the Large-Scale Social Restrictions (PSBB) program and Physical Distancing in various regions as a step by the state to prevent the transmission of the virus, it turned out to have a bad impact in terms of economic growth. Indirectly, the current condition disrupts product export and import activities and weakens or slows down the pace of investment. In addition, it occurs because of the difficulty of entering investment from outside.

Furthermore, many productive workers had to drop out of work due to current conditions, causing various industrial sectors to experience a decline in sales due to reduced market demand, such as the textile industry and the garment industry based on mass production of clothing. The number of people who have experienced layoffs at this time makes the unemployment rates higher. This condition also significantly impacts the marketing activities of various kinds of products needed by the community in Aceh Province. It is closely related to people's purchasing power, marketing models, and purchasing models following the developments of the covid-19 pandemic era. Consumer buying behavior is a picture that explains the wants and needs of consumers both in the short and long term. Consumers have a wide variety of conditions and know more about what they buy to meet their needs and wants (Effendi, Ginting, Lubis \& Fachruddin, 2015). Perceived usefulness has a positive relationship with intentions (Jamal \& Sharifuddin, 2015). The crucial role of perceived usefulness is demonstrated. Only when reviews are perceived as relatively useful, recall of positive and negative review information affects attitude and intention formation through the impression it creates about the object (Purnawirawan, Pelsmacker, \& Dens, 2012). Consumers form their usefulness evaluations depending on the respective shopping tasks (Sohn, 2017). A previous study on travelers figured that highrisk-averse travelers find negative online reviews more useful than positive reviews (Casaló, Flavián, Guinalíu, \& Ekinci, 2015). Perceived risk influences a consumer's intention to purchase and thus mitigates perceived value's role as a motivator, prompting the consumer to purchase online. The style, usefulness, and ease of use are the most crucial e-store image attributes (Chang \& Tseng, 2013). This condition can also be a strong reason why consumers decide to make a purchase and what factors strongly encourage it to influence their decision to make a purchase. It is feared that the increasing spread of the covid19 virus will affect the community's quality of life. It happens because of the limited space of the community in accessing products for consumption needs. The implementation of PSBB is the government's effort to contain the movement of the deadly virus. People must stay at home without exception until a time limit that the government cannot determine. Thus, the 
consumption pattern of the once very consumptive people suddenly decreased drastically due to these restrictions, and producers also experienced very abnormal limitations. It has also become common for all societies to adapt by themselves in a limited environment. For assessing these conditions, it can be seen that the marketing theory based on the marketing mix proposed by Kotler (2000) is now undergoing a shift. In this case, the community is more concerned with fulfilling basic needs to support them to survive. The situation has changed people's perceptions into a new psychological level in determining their purchase decision on basic necessities. In normal situations, products, prices, and places can directly influence buying decisions, but it will lead to other results in an emergency. Therefore, in line with the present issue, it is important to reevaluate the public's purchasing ability and analyze the usage of e-marketing as a model of consumer buying decision during the covid-19 pandemic in Aceh province, Indonesia.

\section{Literature Review}

\subsection{Consumer Behavior}

The needs and desires of consumers are certainly very varied and can change because of the factors that encourage consumers to make purchases. Therefore, a marketer is seen as necessary to understand the behavior of consumers and potential consumers so that the marketing activities carried out can run effectively and efficiently. Consumer buying behavior refers to the buying behavior of the final consumer. Many factors, specificities, and characteristics influence the individual and the consumer in decision-making, shopping habits, buying behavior, the brand, or the retailer (Ramya and Ali, 2016). Consumer behavior describes the actions taken by individuals, groups, or organizations related to the decision-making process to obtain, use economic goods or services that can be influenced by the environment (Foxall, 2015). Understanding the picture of consumer behavior is not an easy job, but it can be difficult and complex. It is due to many influencing variables, and these variables tend to interact with each other. However, if consumer behavior can be understood, a company will get much greater profits because it can serve and provide better customer satisfaction. Consumer behavior is studied for two main reasons: (i) Consumer behavior is very important in everyday life. If only every consumer had constant behavior, perhaps the study of consumer behavior could be less critical. However, consumers are constantly interacting with their environment, their behavior can automatically change, even in a matter of days. Therefore, consumer behavior here is to understand why and what can affect changes in consumer behavior. (ii) Consumer behavior is important for marketers' decision-making. Every decision taken by consumers must be based on certain reasons, either directly or indirectly. Thus, marketers need to understand and study consumer behavior and place consumers as the central point of marketing attention. By understanding consumers, it will direct marketers to more appropriate and efficient marketing policies. In other words, the study of consumer behavior aims to discover and understand various aspects of consumers, which will be used to formulate successful marketing policies.

\subsection{Consumer Buying Decision}

The decision is a selection of two or more choices (Schiffman \& Kanuk, 2010). Decisions always require a choice between different behaviors. Five roles occur in buying decisions: a. Initiator b. Influencers c. Decision maker (decider) d. Buyer e. User (Simamora, 2002). Consumer buying decision behavior can occur through the expression of consumer needs (Goenadhi, 2011). The decision to buy does not happen immediately, but through a process caused by various things that can influence the buyer, so it is necessary to study how consumers make their decisions when they make a purchase. According to Peter and Olson (2013), buying decision knowledge to evaluate two or more alternative behaviors and choose one of them. Consumer decisions in changing, suspending, or canceling to buy are heavily influenced by one's risk view so that consumers do not get any certainty about the consequences of their purchases. Therefore, consumers must make certain strategies to reduce risks, such as canceling decisions, gathering information from the environment, and choosing one of the dominant brands. In this case, after choosing one alternative, the consumer evaluates whether the chosen alternative meets his needs and expectations immediately after using the product he bought. As a result, consumers will experience some level of satisfaction or dissatisfaction. Consumers will also take several actions after buying a product. For example, if the product exceeds expectations, the consumer will be very satisfied. On the other hand, if the product is below the expected level, the consumer will be dissatisfied. Consumers form their rewards based on messages they get from sellers, friends, and other sources of information. If the seller exaggerates the product's benefits, consumers will experience unfulfilled expectations, leading to dissatisfaction. The more significant the gap between expectations and achievements, the greater the consumer dissatisfaction. In such a situation, how the consumer's solving style will play a role arises. Some consumers will exaggerate the gap if the product is not perfect, and they become dissatisfied. These things are also the basis for encouraging sellers to explain the achievements of the products and services they sell frankly and honestly so that buyers can experience satisfaction and not feel cheated.

\subsection{Perceived Ease of Use}

Perception of Ease of Use is the degree to which a person believes that information technology is accessible and does not require hard work from the user (Davis, Bagozzi, \& Warshaw, 1989). Attitude to the use of something is an attitude of liking or disliking the use of a product. The attitude of liking or disliking a product can be used to predict the behavior of a person's intention to use a product or not to use it. Next, Cho and Sagynov (2015) said that the customer's intention to buy a product is primarily determined by their perception of the ease of using the product. According to Oroh, Saerang, and Rumokoy (2015), Internet-based (online) businesses will provide customers with clear information about perceived ease of use with 
minimal effort and enable consumers to shop in a way that benefits them. The ease of use of an online shopping site relates to whether or not potential buyers use the site. The components on the device are complex and challenging to learn, and device users tend to discourage their intention to shop online. The complexity of using online shopping sites is influenced by several factors such as the length of time to open the site, the poor layout, and the menu's layout is not neat (Ramayah and Ignatius, 2005). User perceptions about the ease of use of digital marketing platforms can influence consumer interest in purchasing products. According to Lukitoningtyas and Iriawan (2010), the measures used for perceived ease of use are 1) that the map is easier to use, 2) it is clear and easy to understand, and 3) the map can meet the user's wishes. Furthermore, according to Sun and Zhang, 2006), identified indicators of perceived ease, namely, ease to learn, ease to use, clear and understandable, and become skillfulness.

\subsection{Perceived Usefulness}

Perception of product usability is the perception of usefulness as a construct of a person's belief that using a particular technology will improve their performance (Adamson \& Shine, 2003). Perceived usefulness is the degree to which a person believes that using a system will improve that person's performance (Irmadhani and Nugroho, 2012). For example, for emarketing platform users who transact during peak hours, accessibility and transaction speed can be beneficial features (Cho \& Sagynov, 2015). Perceived usefulness is the extent to which the perceived benefits that someone from a particular system will feel to improve their work performance (Mathwick, Malhotras, \& Rigdon, 2001). When a person feels confident that the system is useful, then he will use it. Conversely, if someone believes that the information system is less useful, he will not use it. This concept also describes the benefits of the system for users related to productivity (productivity), job performance or effectiveness (task performance or effectiveness), importance to the job (importance for tasks), and overall usefulness (Venkatesh \& Davis, 2000). Perceived usefulness is the subjective probability of potential users using a particular application to facilitate their work performance. This simplified performance can produce better benefits in terms of physical and nonphysical, such as the results obtained will be faster and with more satisfying results in providing benefits compared to not using products with the new technology. The consumer's direct perception is through the perception of the benefits or usability of the product. The indicator used to measure the perceived usefulness variable is that online banking can improve performance and increase productivity and effectiveness so that online banking is considered to provide benefits in carrying out customer duties or jobs (Irmadhani \& Nugroho, 2012). Meanwhile, Adhiputra (2015) conceptualized that perceived usefulness can be measured through indicators: a) Can improve job performance. b) Make work easier. c) The technology used is felt to be useful. Whereas (Ahmad \& Pambudi, 2013) revealed that user perceptions of the benefits of technology could be measured from several factors as follows: a) The use of technology can increase user productivity. b) The use of technology can improve the performance of workers. c) The use of technology can increase the efficiency of processes carried out by users. Jogiyanto (2007) said to form a useful perception construct using six items: (i) Work more quickly, (ii) Job performance, (iii) Increase Productivity, (iv) Effectiveness, (v) Makes Jobs easier, and (vi) Useful.

\subsection{Perceived Risk}

The perceived risk is a crucial factor for consumers to consider when shopping online (Suleman, 2018). This statement follows the research results conducted by (Saleh, Mamman, \& Midawa, 2016) that the perception of risk affects online shopping decisions. Next (Jordan, Leskovar, \& Marič, 2018) conducted a study showing that risk perception partially has a significant influence on online shopping decisions. On the other hand, (2018) stated that the perception of risk negatively influences. AlRawad, Al Khattab, Al-Shqairat, Krishan, and Jarrar (2015) added that the perceived risk in the context of financial risk does not affect online shopping behavior, while product risk affects online shopping decisions. Jordan et al. (2018) showed no significant effect of perceived risk on online shopping decisions. This study measures perceived risk by several indicators, namely performance, financial, and security.

\section{Methodology}

This study was designed using a quantitative approach through cross-sectional research and involved 325 consumers in Aceh Province, Indonesia. The data was collected through a survey by filling out the questionnaires. e-marketing is measured by perceived usefulness, perceived ease of use as exogenous variables. Therefore, perceived risk is a mediating variable, and the consumer buying decision is an endogenous variable. Hypothesis testing in this study used Structural Equation Modelling Analysis of Moments Structure (SEM-AMOS) by assisting statistical software, namely IBM-AMOS. SEM-AMOS is used to examine the relationship between variables and their measurement errors. The proposed hypotheses are as follows:

$\mathbf{H}_{1}$ : Perceived usefulness has a positive and significant effect on the consumer buying decision.

$\mathbf{H}_{2}$ : Perceived ease of use has a positive and significant effect on the consumer buying decision.

$\mathbf{H}_{3}$ : Perceived risk moderates the relationship between perceived usefulness and the consumer buying decision.

H4: Perceived risk moderates the relationship between perceived ease of use and the consumer buying decision. 


\section{Results and Discussion}

\subsection{Demography Profile of Respondents and Descriptive Statistics}

This section reports the demography profile of respondents, which aims to explain the percentage and frequency of participated respondents. Characteristics of respondents consist of gender, age, marital status, education level, and marketplace. The result of the analysis, as seen in Table 2 below:

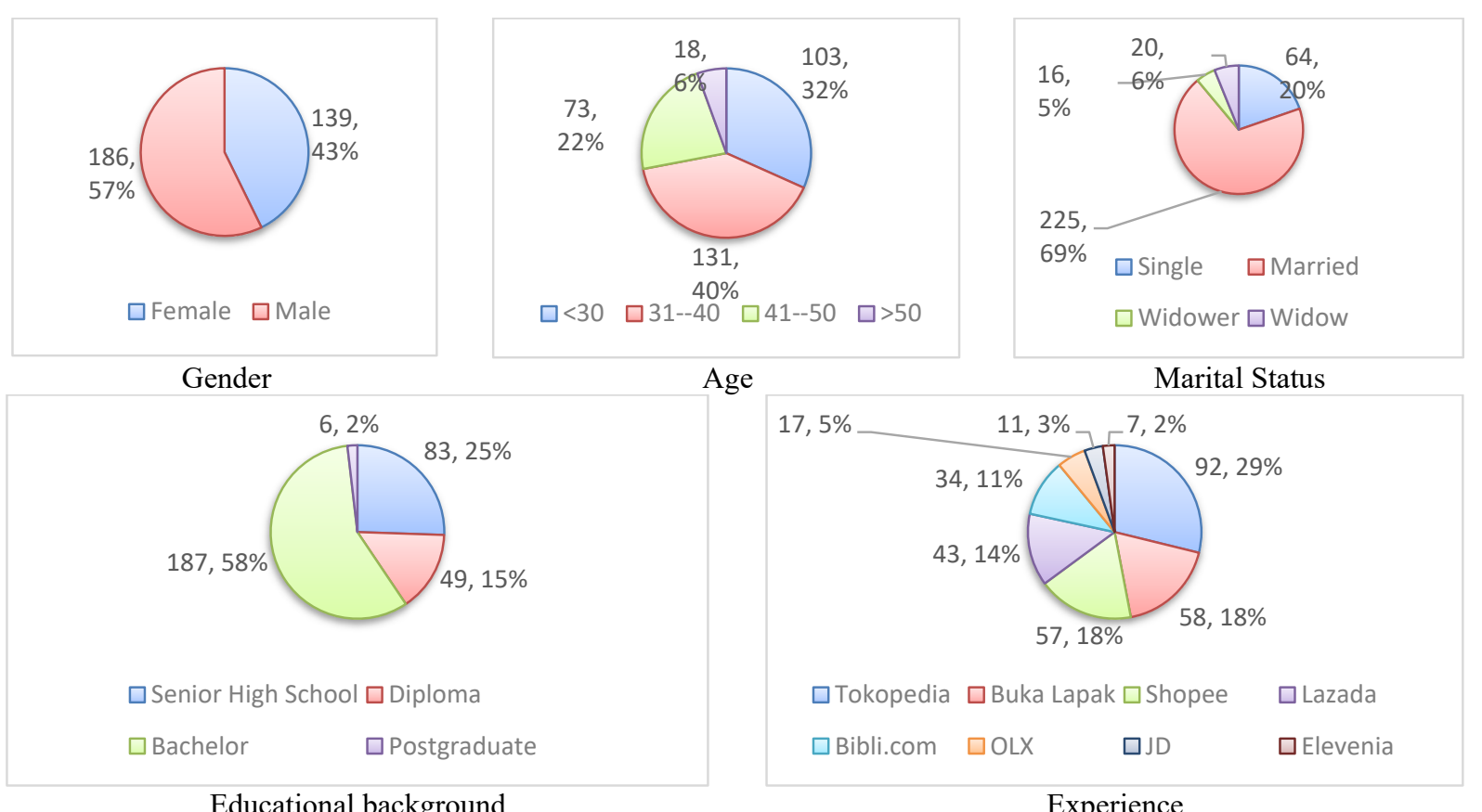

Educational background

Experience

Fig. 1. Results of Demography Profile of Respondents

Table 2 shows the results of the demographic profile of respondents. This study indicated that the majority of respondents are male, with 186 respondents or 57.2 percent. Meanwhile, the female respondents are 139 or 42.8 percent. Thus, this study was dominated by male respondents. For the age of respondents, most respondents were dominated by aged 31 to 40 years with 131 respondents or 40.3 percent. It was followed by the respondents aged below and equal to 30 years with 103 respondents, or 31.7 percent, aged below and equal to 30 years. Thus, 131 respondents, or 40.3 percent, are aged 31 - 40 years. Respondents aged 41-50 years are 73 respondents or 22.5 percent, and those aged above 50 years were as many as 18 respondents or 5.5 percent. Marital status of respondents; the majority are married as much as 225 respondents or 69.2 percent. It was followed by as many as 64 respondents or 19.7 percent. The widow is 20 respondents or 6.2 percent, and widower is 16 respondents or 4.9 percent. Most respondent's education level is bachelor as much as 187 or 57.5 and followed by senior high school as many as 83 or 25.5 percent. Only 6 respondents are postgraduate, or 1.8 percent. For the marketplace, most respondents were choosing Tokopedia as much as 92 respondents or 28.3 percent and followed by Buka Lapak with 58 respondents or 17.8 percent. Shopee is 57 respondents or 17.5 percent. Only 7 respondents, or 2.2 percent, were chosen to shop in Elevenia as an online marketplace. Thus, the digital platform brands most visited and used by consumers are Tokopedia, Shopee, and Bukalapak and categorized as popular brands in Indonesia. Next, this study presents and elaborates the results of descriptive statistics using mean and standard deviation. The results were interpreted using the proposed threshold by Nunnally and Bernstein (1994), which is the value of 1 to 2.33 categorized as low, 2.34 to 3.66 is medium, and 3.67 to 5 is high. The results of descriptive statistics can be seen in table 3 as follow:

Table 2

Descriptive Statistics (mean and standard deviation)

\begin{tabular}{cccc}
\hline Variable(s) & Mean & Standard Deviation & \\
\hline Perceived Usefulness & 3.62 & 0.871 & Decision \\
Perceived Ease of Use & 3.55 & 0.832 & Medium \\
Perceived Risk & 3.45 & 0.834 & Medium \\
Buying Decision & 3.60 & 0.809 & Medium \\
\hline
\end{tabular}

Table 2 displays the result of descriptive statistics. This study found that the mean value of Perceived Usefulness is 3.62 with a standard deviation of as much as 0.871 . The perceived Ease of Use mean value is 3.55 , with a standard deviation as big as 0.832 . For the variable of Perceived Risk, the mean value is 3.45 , and the standard deviation is 0.834 . Finally, the mean value of Buying decisions is 3.60, and the standard deviation is 0.809 . Overall, this study indicated that the level of Perceived 
Usefulness, Perceived Ease of Use, Perceived Risk, and Buying Decision variables were categorized as a medium ranging from 2.34 to 3.66 (Nunally and Bernstein, 1994).

\subsection{Measurement Model}

Before embarking on inferential statistics, this study elaborates the measurement - the measurement model consisting of item loadings, validity and reliability, and discriminant validity. For measuring construct validity and reliability, this study uses the value of loading factor, composite reliability (CR), and average variance extracted (AVE). Composite reliability is used to overcome deficiencies in measurements using Cronbach's alpha (Chin, 1998). The composite reliability value should be equal to or higher than 0.70 (George and Mallery, 2003; Nunally and Bernstein, 1994). Construct validity can prove the extent to which the results of using a measurement are in line with the theory (Sekaran and Bougie, 2003). The validity of this construct is usually tested with convergent validity (AVE) and discriminant validity using Fornell and Larcker Criterion (Hung, Chang, and Hwang, 2011). Table 4 below shows results of construct validity and reliability.

Table 4

Results of Construct Validity and Reliability

\begin{tabular}{|c|c|c|c|c|c|}
\hline \multicolumn{3}{|c|}{ Indicator(s) } & Loadings & Composite Reliability & Average Variance Extracted \\
\hline PU_1 & $\leftarrow$ & Perceived Usefulness & 0.759 & \multirow{4}{*}{0.828} & \multirow{4}{*}{0.739} \\
\hline PU_2 & $\leftarrow$ & Perceived Usefulness & 0.742 & & \\
\hline PU_3 & $\leftarrow$ & Perceived Usefulness & 0.747 & & \\
\hline PU 4 & $\leftarrow$ & Perceived Usefulness & 0.709 & & \\
\hline PE_1 & $\leftarrow$ & Perceived Ease of Use & 0.780 & \multirow{4}{*}{0.818} & \multirow{4}{*}{0.728} \\
\hline PE_2 & $\leftarrow$ & Perceived Ease of Use & 0.741 & & \\
\hline PE_3 & $\leftarrow$ & Perceived Ease of Use & 0.690 & & \\
\hline $\mathrm{PE} 4$ & $\leftarrow$ & Perceived Ease of Use & 0.698 & & \\
\hline PR_1 & $\leftarrow$ & Perceived Risk & 0.715 & \multirow{4}{*}{0.800} & \multirow{4}{*}{0.708} \\
\hline PR_2 & $\leftarrow$ & Perceived Risk & 0.675 & & \\
\hline PR_3 & $\leftarrow$ & Perceived Risk & 0.720 & & \\
\hline PR_ 4 & $\leftarrow$ & Perceived Risk & 0.720 & & \\
\hline BD_1 & $\leftarrow$ & Buying Decision & 0.718 & \multirow{4}{*}{0.811} & \multirow{4}{*}{0.720} \\
\hline $\mathrm{BD} 2$ & $\leftarrow$ & Buying Decision & 0.686 & & \\
\hline $\mathrm{BD} \_3$ & $\leftarrow$ & Buying Decision & 0.747 & & \\
\hline $\mathrm{BD} 4$ & $\leftarrow$ & Buying Decision & 0.728 & & \\
\hline
\end{tabular}

Table 4 captures the result of construct validity and reliability. The result shows that the value of loadings factors is higher than 0.50 , composite reliability exceeds the minimum value of 0.70 , and the value of AVE is greater than 0.50 . Thus, it indicates that all the instruments in this study are valid and reliable. In the next section, this study reports the result of discriminant validity using Fornell and Larcker Criterion.

Table 4

Results of Discriminant Validity using Fornell and Larcker Criterion

\begin{tabular}{cccc}
\hline Construct & Perceived Usefulness & Perceived Ease of Use & Perceived Risk \\
\hline Perceived Usefulness & $\mathbf{0 . 7 3 9}$ & & \\
Perceived Ease of Use & 0.106 & $\mathbf{0 . 7 2 8}$ & \\
Perceived Risk & 0.547 & 0.447 & $\mathbf{0 . 7 0 8}$ \\
Buying Decision & 0.620 & 0.471 & 0.753 \\
\hline
\end{tabular}

Table 4 describes the results of discriminant validity using Fornell and Larcker criterion. This study found that the square root value of AVE for each construct was higher than the correlation of other constructs (Fornell \& Cha, 1994; Fornell and Larcker, 1981; Henseler, Ringle, \& Sinkovics, 2009). In addition, this study provides the results of correlation testing via CFA $4^{\text {th }}$ factor structures. The correlation coefficients are used to measure how strong a relationship is between two variables. The correlation coefficient can be interpreted using the condition of estimate value that is 0.70 or higher categorized as very strong, 0.40 to 0.69 is strong, 0.30 to 0.39 is moderate. 0.20 to 0.29 is weak, and 0.01 to 0.19 is negligible correlations (Edwards, 1984). The results can be seen in Table 5:

Table 5

Results of Correlation Estimate (CFA $4^{\text {th }}$ factors structures)

\begin{tabular}{|c|c|c|c|c|}
\hline & Correlation & & Estimate & Decision \\
\hline Perceived Usefulness & $\leftrightarrow$ & Perceived Risk & 0.547 & Strong \\
\hline Perceived Ease of Use & $\leftrightarrow$ & Perceived Risk & 0.447 & Strong \\
\hline Perceived Ease of Use & $\leftrightarrow$ & Buying Decision & 0.471 & Strong \\
\hline Perceived Usefulness & $\leftrightarrow$ & Perceived Ease of Use & 0.106 & Negligible \\
\hline Perceived Usefulness & $\leftrightarrow$ & Buying Decision & 0.620 & Strong \\
\hline Perceived Risk & $\leftrightarrow$ & Buying Decision & 0.753 & Very Strong \\
\hline
\end{tabular}


Table 5 displays the result of the correlation estimate. This study found that Perceived Risk correlates with Buying decisions as much as 0.753 or 75.3 percent and was categorized as a very strong positive correlation. Furthermore, perceived Usefulness and Perceived Risk, Perceived Ease of Use and Perceived Risk, Perceived Ease of Use and Buying Decision, Perceived Usefulness and Buying Decision were categorized as strong positive correlation (correlation coefficients are ranged 0.447 to 0.620). Only Perceived Usefulness has a negligible correlation with Perceived Ease of Use.

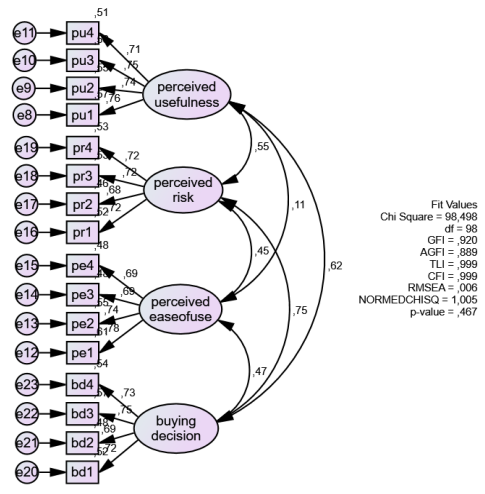

Fig. 2. The result of confirmatory factor analysis using four factors model

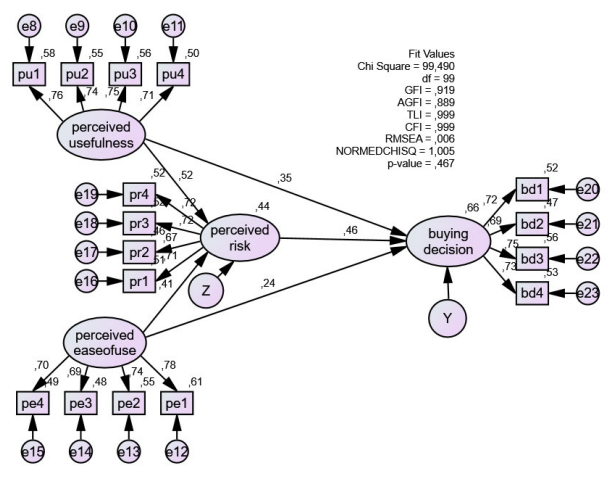

Fig. 3. The result of Structural Equation Modelling using Analysis of Moments Structure

\subsection{Structural Model}

Three groups of the goodness of fit (GoF) measures are available, namely absolute, incremental, and parsimony fit indices. However, it is not expected that all of these would be reported. It rather depends on the purpose for which the work is intended. Absolute Fit Indices assess how well a researcher's theoretical model fits the observed data. The only statistically based measure of fit is that of the Likelihood Ratio Test, or known as Chi-square" (CMIN/DF) statistic and its associated "probability" or p-value - which should not be statistically significant if there is a good model fit. However, the Chi-Square statistic is very sensitive to sample size and is no longer relied upon as a basis for acceptance or rejection (Schlermelleh-Engel et al., 2003, Vandenberg 2006). As a result, the use of multiple fit indexes has developed to provide a more holistic view of GOF, considering sample size and model complexity and other relevant issues of the study.

Table 6

Results of Goodness of Fit (GoF)

\begin{tabular}{cccc}
\hline Goodness of Fit & Threshold(s) & Result(s) & Decision \\
\hline$X^{2}$-Chi-Square & Expected smallest & 9.490 & 0.467 \\
Probability & $\geq 0.05$ & 0.919 & Achieved \\
GFI & $\geq 0.90$ & 0.889 & Achieved \\
AGFI & $\geq 0.90$ & 0.999 & Achieved \\
CFI & $\geq 0.95$ & 0.999 & Achieved \\
TLI & $\geq 0.95$ & 1.005 & Achieved \\
CMIN/DF & $\leq 2.00$ & 0.006 & Achieved \\
RMSEA & $\leq 0.08$ & Achieved &
\end{tabular}

By applying three types of GoF indices, this study found that the results obtained from actual data (observed) fit with the theoretical model (refer to Table 6). Furthermore, the collected data is used to test the proposed hypotheses. The structural model in this study is outlined in Fig. 3. Based on the results of the structural model test, the influence of exogenous variables (perceived usefullness and perceived ease of use) on endogenous variables (perceived risk and buying decisions), as shown in Table 7 below:

Table 7

Results of hypotheses testing for direct effect

\begin{tabular}{|c|c|c|c|c|c|c|c|}
\hline & & & Std. Estimate & Unstd. Estimate & S.E. & C.R. & $\mathrm{P}$ \\
\hline Consumer Buying Decision & $\leftarrow$ & Perceived Usefulness & 0.353 & 0.288 & 0.091 & 3.152 & 0.002 \\
\hline Consumer Buying Decision & $\leftarrow$ & Perceived Ease of use & 0.238 & 0.194 & 0.082 & 2.359 & 0.018 \\
\hline Perceived Risk & $\leftarrow$ & Perceived Usefulness & 0.520 & 0.473 & 0.098 & 4.837 & $* * *$ \\
\hline Perceived Risk & $\leftarrow$ & Perceived Ease of use & 0.408 & 0.370 & 0.090 & 4.112 & $* * *$ \\
\hline Consumer Buying Decision & $\leftarrow$ & Perceived Risk & 0.464 & 0.418 & 0.123 & 3.386 & $* * *$ \\
\hline
\end{tabular}


Table 7 shows the results of hypotheses testing for direct effect. This study found that perceived usefulness has a significant and positive effect on the consumer buying decision. The value of the standardized regression coefficient of perceived usefulness to consumer buying decision was 0.353, C.R is 3.152 and significant at the level $p<0.01$. It means that assuming an increase in perceived usefulness of 1 percent would increase consumer buying decisions by as much as 35.3 percent. Also, perceived ease of use has a significant and positive effect on the consumer buying decision. The value of the standardized regression coefficient of perceived ease of use to consumer buying decision was 0.238 , C.R is 2.359 and significant at the level $\mathrm{p}<0.05$. It means that assuming an increase in perceived ease of use for 1 percent would increase consumer buying decisions by as much as 23.8 percent. Thus, the proposed hypotheses are supported. In addition, this study found that perceived usefulness has a significant and positive effect on perceived risk. The value of the standardized regression coefficient of perceived usefulness to perceived risk was 0.520, C.R is 4.837 and significant at the level $p<0.001$. It means that assuming an increase in perceived usefulness of 1 percent would affect increasing perceived risk by as much as 52 percent. Furthermore, perceived ease of use has a significant and positive effect on perceived risk. The value of the standardized regression coefficient of perceived ease of use to perceived risk was 0.408, C.R is 4.112 and significant at the level $\mathrm{p}<0.001$. It means that assuming an increase in perceived ease of use for 1 percent would increase perceived risk by as much as 40.8 percent. Furthermore, this study found that perceived risk has a significant and positive effect on the consumer buying decision. The value of the standardized regression coefficient of perceived risk to consumer buying decision was 0.464 , C.R is 3.386 and significant at the level $\mathrm{p}<0.001$. It means that assuming an increase in perceived risk of 1 percent would increase consumer buying decisions by as much as 46.4 percent. For mediating the role of perceived risk, this study uses the Sobel test. The result of Sobel test for mediating role of perceived risk in the relationship between perceived usefulness and consumer buying decision, as seen in Fig. 4 below:

\begin{tabular}{|c|c|c|c|c|}
\hline \multicolumn{5}{|c|}{ Wakn knont } \\
\hline 0.52 & Wobeutest & 3.07454516 & 0.07847665 & 0.00210824 \\
\hline 00.464 & Aroian test & 3.03890583 & 0.079397 & 0.00237439 \\
\hline $5=0.098$ & Goodmantest & 3.11146853 & 0.07754538 & 0.00186159 \\
\hline 0.123 & Reset al] & \multicolumn{3}{|c|}{ Calculate } \\
\hline
\end{tabular}

Fig. 4. The result of Sobel test for mediating role of perceived risk for perceived usefulness and consumer buying decision

Fig. 3 displays the result of calculations using the Sobel calculator. The result produces a value of the statistical test is 3.074 or higher than 1.96 , and the p-value is $0.002<0.01$ and a standard error of 0.078 . Therefore, it means that perceived risk partially mediates the relationship between perceived usefulness and consumer buying decision. Thus, the proposed hypothesis is supported. Also, Fig. 5 captures the step-by-step summary of hypothesis testing.

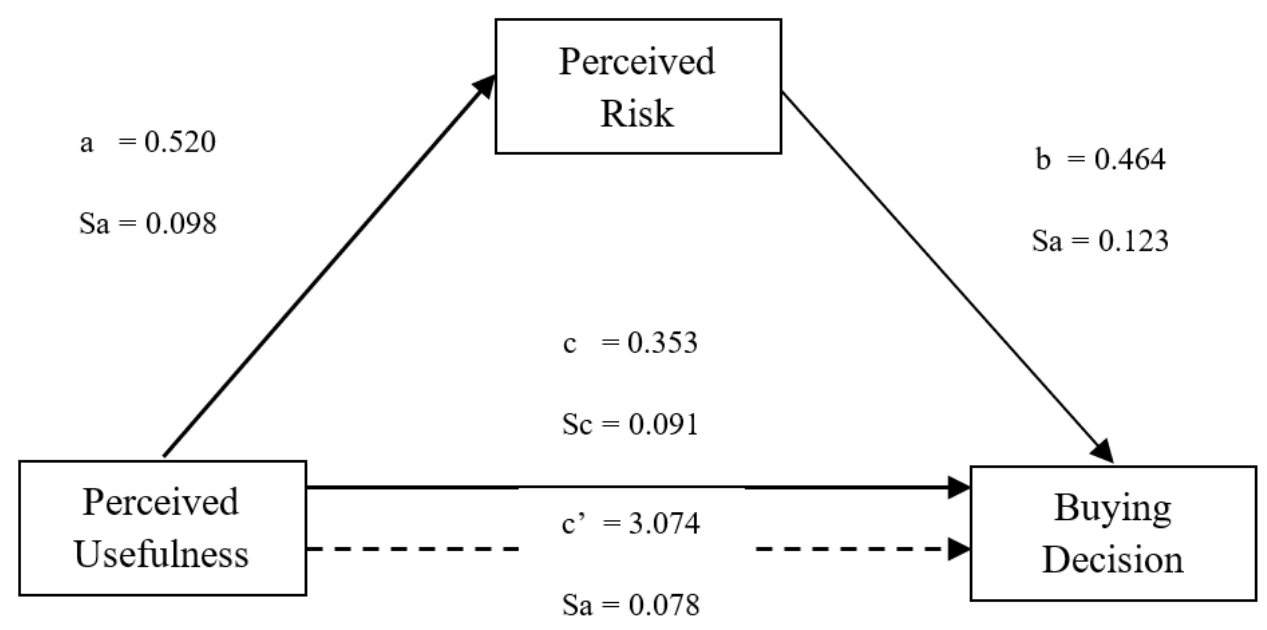

Fig. 5. The mediating role of perceived risk in the relationship between perceived usefulness and consumer buying decision

Further, the result of Sobel test for mediating role of perceived risk in the relationship between perceived ease of use and consumer buying decision, as seen in Fig. 6 below: 


\begin{tabular}{|c|c|c|c|c|c|}
\hline \multicolumn{6}{|c|}{ 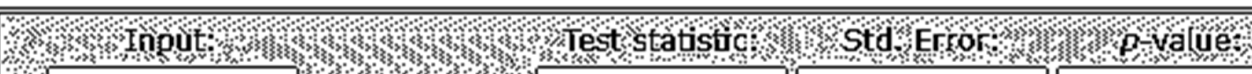 } \\
\hline$a$ & 0.408 & ys sobef test & 2.89970978 & 0.06528653 & 0.00373508 \\
\hline$b$ & 0.464 & Arolanotest & 2.85890331 & 0.0662184 & 0.00425108 \\
\hline Sa & 0.090 & Goodnan test & 2.94231502 & 0.06434117 & 0.00325768 \\
\hline 35 & 0.123 & Reset all & & Calculate & \\
\hline
\end{tabular}

Fig. 6. The result of Sobel test for mediating role of perceived risk for perceived ease of use and consumer buying decision

Fig. 6 shows the Sobel test result for mediating the role of perceived risk for perceived ease of use and consumer buying decision. The result produces a value of the statistical test is 2.897 or higher than 1.96 , and the p-value is $0.003<0.01$ and a standard error of 0.065 . Thus, perceived risk partially mediates the relationship between perceived ease of use and consumer buying decision. Therefore, the proposed hypothesis is supported. Also, Fig. 7 captures the step-by-step summary of hypothesis testing.

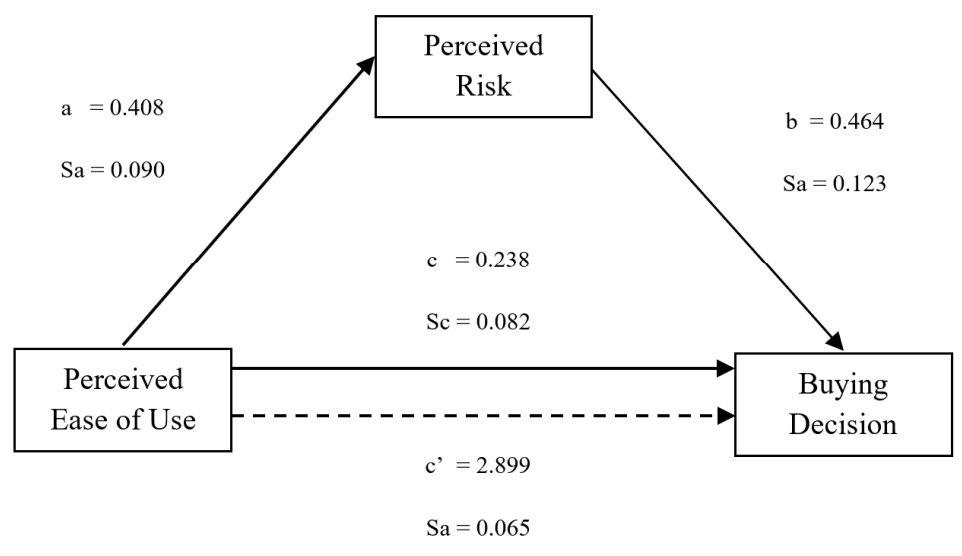

Fig. 6. The mediating role of perceived risk in the relationship between perceived ease of use and consumer buying decision

\subsection{Discussion}

Perceived usefulness refers to the degree to which a person believes that using a system will improve that person's performance (Irmadhani \& Nugroho, 2012). Also, perceived usefulness is the extent to which the perceived benefits that someone from a particular system will feel to improve their work performance (Mathwick, Malhotras, \& Rigdon, 2001). For example, for emarketing platform users who transact during peak hours, accessibility and transaction speed can be beneficial features (Cho \& Sagynov, 2015). This study indicated that perceived usefulness has a significant and positive effect on consumer buying decisions during the COVID-19 pandemic in Aceh province, Indonesia. This finding supported by Ashghar and Nurlatifah (2020) found that perceived usefulness had a significant relationship with online repurchase intention. Also, Gusni, Hurriyati and Dirgantari (2020) and Oentario, Harianto and Irawati (2017) stated that people's perceptions of the usefulness of products are one of the important reasons for making online buying decisions. Further, this study indicated that perceived ease of use has a significant and positive effect on consumer buying decisions during the COVID-19 pandemic in Aceh province, Indonesia. A similar finding obtained by Ashghar and Nurlatifah (2020) found a significant relationship between perceived ease of use of media and online product buying decisions. It was also conveyed by Gusni et al. (2020) and Oentario et al. (2017), who stated that people perceive the online product purchasing system well. Also, perceived risk has a significant and positive effect on consumer buying decisions during the COVID-19 pandemic in Aceh province, Indonesia. It means that the usability of the product can influence consumers in buying decisions during the covid-19 pandemic. These results strengthen previous research findings, such as research (Ashghar \& Nurlatifah, 2020; Wu et al., 2020), which stated that perceived risk affects people's decisions in purchasing online products.

Besides that, this study examines the mediating role of perceived risk in the relationship between perceived usefulness and ease of use on consumer buying decisions. This study indicated that perceived risk partially mediates the relationship between perceived usefulness and consumer buying decision. This finding is supported by Ashghar and Nurlatifah (2020), who found that perceived risk mediates the relationship between perceived usefulness and buying decisions. In addition, perceived risk partially mediates the relationship between perceived ease of use and consumer buying decision. A similar finding reported by Ashghar and Nurlatifah (2020) mentioned that people always consider various risks in making purchases through online media. 


\section{Conclusion}

In conclusion, this study has successfully examined the relationship between e-marketing via perceived usefulness and perceived ease of use. Also, it proves that perceived risk plays a mediating role (partial mediator) in the relationship of perceived usefulness and ease of use on consumer buying decisions. This study also found that e-marketing using digital platform brands most visited and used by the community to buy their needs are Tokopedia, Shopee, and Bukalapak. Thus, this tested model has been formulated for marketing science during the covid-19 pandemic. Therefore, the buying decision model in the marketplace is a function of consumers' perceived usefulness and ease of use towards the marketplace and the perceived risk of the marketplace as a partial mediator. So that marketplace manufacturers can drive the strengthening of the decision to buy by consumers by creating a strengthening of perceived usefulness and perceived ease of use for consumers, thereby affecting consumers' perceived risk and impacting their decision to buy. For further researchers, this study recommended developing this tested model by adding other variables such as age and gender as moderator variables and digital literacy as an antecedent variable. Furthermore, the regulator (government) needs to prepare adequate infrastructure related to online buying and selling activities for practical advice. Also, business actors need to make preventive efforts in building virtual (online) based business activities. Finally, for the consumer community, it is necessary to strengthen knowledge related to online buying and selling activities, to facilitate buying and selling activities during the covid-19 pandemic.

\section{References}

Adamson, I., \& Shine, J. (2003). Extending the new technology acceptance model to measure the end user information systems satisfaction in a mandatory environment: A Bank's Treasury. Technology Analysis and Strategic Management, 15(4), 441455. https://doi.org/10.1080/095373203000136033

Adhiputra, M. W. (2015). Aplikasi Technology Acceptance Model Terhadap Pengguna Layanan Internet Banking. Kalbisocio, 2(1), 52-63.

Ahmad, \& Pambudi, B. S. (2013). Pengaruh Persepsi Manfaat, Persepsi Kemudahan, Keamanan Dan Ketersediaan Fitur Terhadapminat Ulang Nasabah Bank Dalam Menggunakan Internet Banking (Studi Pada Program Layanan Internet Banking Bri). Journal of Chemical Information and Modeling, 53(9), 1689-1699. https://doi.org/10.1017/CBO9781107415324.004

Al-Rawad, M. I., Al Khattab, A., Al-Shqairat, Z. I., Krishan, T. A., \& Jarrar, M. H. (2015). An Exploratory Investigation of Consumers' Perceptions of the Risks of Online Shopping in Jordan. International Journal of Marketing Studies, 7(1). https://doi.org/10.5539/ijms.v7n1p157

Ashghar, S. A., \& Nurlatifah, H. (2020). Analisis Pengaruh Perceived Ease of Use, Perceived Usefulness, dan Perceived Risk terhadap Keinginan Membeli Kembali melalui e-Trust dan s-Satisfaction (Studi Kasus Pengguna Gopay pada Transaksi UMKM). Jurnal Al Azhar Indonesia Seri Ilmu Sosial, 1(1), 40. https://doi.org/10.36722/jaiss.v1i1.459

Casaló, L. V., Flavián, C., Guinalíu, M., \& Ekinci, Y. (2015). Avoiding the dark side of positive online consumer reviews: Enhancing reviews' usefulness for high risk-averse travelers. Journal of Business Research, 68(9), 1829-1835. https://doi.org/https://doi.org/10.1016/j.jbusres.2015.01.010

Chang, E.-C., \& Tseng, Y.-F. (2013). Research note: E-store image, perceived value and perceived risk. Journal of Business Research, 66(7), 864-870. https://doi.org/https://doi.org/10.1016/j.jbusres.2011.06.012

Cho, Y. C., \& Sagynov, E. (2015). Exploring Factors That Affect Usefulness, Ease Of Use, Trust, And Purchase Intention In The Online Environment. International Journal of Management \& Information Systems, 19(1).

Davis, F., Bagozzi, R., \& Warshaw, P. (1989). User Acceptance of Computer Technology: a Comparison of Two Theoretical Models. Management Science. Aug1989, 35(8), 982-1003. https://doi.org/10.2307/2632151

Edwards, A. L. (1984). An introduction to linear regression and correlation (No. 04; QA278. 2, E3 1984.).

Effendi, I., Ginting, P., Lubis, A. N., \& Fachruddin, K. A. (2015). Analysis of Consumer Behavior of Organic Food in North Sumatra Province, Indonesia. Journal of Business and Management, 4(1), 44-58. https://doi.org/10.12735/jbm.v4i1p44

Fornell, C., \& Cha, J. (1994). Partial least squares. In R. Bagozzi, Ed., Advanced Methods of Marketing Research, Blackwell, Cambridge, 1994, pp. 52-87.

Fornell, C., \& Larcker, D. F. (1981). Evaluating structural equation models with unobservable variables and measurement error. Journal of marketing research, 18(1), 39-50.

Foxall, G. R. (2015). Consumer Behavior Analysis and the Marketing Firm: Bilateral Contingency in the Context of Environmental Concern. Journal of Organizational Behavior Management, 35(1-2), 44-69. https://doi.org/10.1080/01608061.2015.1031426

George, D., \&Mallery, P. (2003). SPSS for Windows step by step: A simple guide and reference. 11.0 update (4th ed.). Boston: Allyn \& Bacon

Ghozali, I. (2017). Model Persamaan Struktural, Konsep dan Aplikasi dengan Program AMOS 24 Update Bayesian SEM (Edisi 7). Semarang: Badan Penerbit Universitas Diponegoro.

Goenadhi, L. (2011). FAKTOR-FAKTOR YANG MEMPENGARUHI PERILAKU KONSUMEN DALAM KEPUTUSAN PEMBELIAN MOBIL TOYOTA AVANZA DI KOTA BANJARMASIN. Jurnal Manajemen Dan Akunta, 12, $155-158$.

Gusni, G., Hurriyati, R., \& Dirgantari, P. D. (2020). Pengaruh Perceived Usefulness dan Perceived Ease of Use terhadap Attitude dan Actual Usage Go-Pay. Jurnal Manajemen Dan Kewirausahaan, 8(1), $22-33$. https://doi.org/10.26905/jmdk.v8i1.3892

Henseler, J., Ringle, C. M., \& Sinkovics, R. R. (2009). The use of partial least squares path modeling in international 
marketing. In New challenges to international marketing. Emerald Group Publishing Limited.

Hung, M.-C., Chang, I., \& Hwang, H.-G. (2011). Exploring academic teachers" continuance toward the web-based learning system: The role of causal attributions. Computers \& Education, 57(2), 1530-1543.

Irmadhani, \& Nugroho, M. A. (2012). Pengaruh Persepsi Kebermanfaatan, Persepsi Kemudahan Penggunaan Dan Computer Self Efficacy, Terhadap Penggunaan Online Banking Pada Mahasiswa S1 Fakultas Ekonomi Universitas Negeri Yogyakarta. Kajian Pendidikan \& Akuntansi Indonesia, 1, 1-20.

Jamal, A., \& Sharifuddin, J. (2015). Perceived value and perceived usefulness of halal labeling: The role of religion and culture. Journal of Business Research, 68(5), 933-941. https://doi.org/https://doi.org/10.1016/j.jbusres.2014.09.020

Jogiyanto. (2007). Sistem informasi keperilakuan. Yogyakarta: andi Offset.

Jordan, G., Leskovar, R., \& Marič, M. (2018). Impact of Fear of Identity Theft and Perceived Risk on Online Purchase Intention. Organizacija, 51(2), 146-155. https://doi.org/10.2478/orga-2018-0007

Kamalul Ariffin, S., Mohan, T., \& Goh, Y. N. (2018). Influence of consumers' perceived risk on consumers' online purchase intention. Journal of Research in Interactive Marketing, 12(3), 309-327. https://doi.org/10.1108/JRIM-11-2017-0100

Kemenkes, R.I. (2020). Situasi Terkini Perkembangan (COVID-19). Kemenkes, 17-19.

Kotler, P. (2000). Marketing Management, Millenium Edition (10th ed.). New Jersey: Prentice-Hall Inc.

Lestari, I. (2020). Terhadap Niat Untuk Menggunakan Kembali Layanan Transportasi Online Di Era Pandemi Covid-19. Equilibrium Volume 9. No. 1. Tahun 2020 Hal 27 - 35, 9(1), 27-35.

Lukitoningtyas, \& Iriawan, N. (2010). (m.8) analisis faktor yang mempengaruhi persepsi manfaat dan persepsi kemudahan penggunaan peta ber-. Prosiding Seminar Nasional Statistika Universitas Padjadjaran, 2010(November), $166-175$.

Malik, A. N. A., \& Annuar, S. N. S. (2021). The Effect of Perceived Usefulness, Perceived Ease of Use, Reward, and Perceived Risk toward E-Wallet Usage Intention. In Eurasian Studies in Business and Economics (Vol. 17, pp. 115-130). https://doi.org/10.1007/978-3-030-65147-3_8

Mathwick, C., Malhotra, N., \& Rigdon, E. (2001). Experiential value: conceptualisation, measurement and application in the catalog and Internet shopping environment. Journal of Retailing, 77(1), 39-56.

Nunally, J. C., \& Bernstein, I. H. (1994). Psychometric Theory. New York: McGraww-Hill.

Oentario, Y., Harianto, A., \& Irawati, J. (2017). Pengaruh Usefulness, Ease of Use, Risk Terhadap Intentionto Buy Onlinepatisserie Melalui Consumer Attitude Berbasis Media Sosial Di Surabaya. Jurnal Manajemen Pemasaran, 11(1), 26-31. https://doi.org/10.9744/pemasaran.11.1.26-31

Oroh, C. R., Saerang, D. P. E., \& Rumokoy, F. S. (2015). The Influence of Perceived Ease of Use, Perceived Usefulness and Trust on Repurchase Intention of Lion Air E-Ticket. Jurnal Berkala Ilmiah Efisiensi, 15(5), 950-958.

Peter, J. P., \& Olson, J. C. (2013). Perilaku Konsumen dan Strategi Pemasaran. In Jakarta: Erlangga. Jakarta: Salemba Empat.

Purnawirawan, N., Pelsmacker, P. De, \& Dens, N. (2012). Balance and Sequence in Online Reviews: How Perceived Usefulness Affects Attitudes and Intentions. Journal of Interactive Marketing, 26(4), 244-255. https://doi.org/https://doi.org/10.1016/j.intmar.2012.04.002

Ramayah, T., \& Ignatius, J. (2005). Impact of Perceived usefulness , Perceived ease of use and Perceived Enjoyment on Intention to Shop Online. ICFAI Journal of Systems Management (IJSM), 1-16.

Ramya, N., \& Ali, S. M. (2016). Factors affecting consumer buying behavior. International Journal of Applied Research, 2(10), 76-80.

Saleh, M., Mamman, H., \& Midawa, M. (2016). EFFECTS OF PERCEIVED RISK ON ONLINE Effects of Perceived Risk on Online Shopping. Proceedings of the 1st Management, Technology, and Development Conference, (August), 318-323.

Sekaran, U. \& Bougie, R. (2003). Research Methods for Business: A Skill Building Approach. Ed. ke-4. John Wiley \& Sons Inc.

Schiffman, L., \& Kanuk, L. (2010). Consumer Behavior (11th ed.). London: Pearson.

Simamora, B. (2002). Panduan riset perilaku konsumen. Jakarta: Gramedia Pustaka Utama.

Suleman, D. (2018). FAKTOR PENENTU KEPUTUSAN KONSUMEN INDONESIA MEMILIH TEMPAT BELANJA DISEBUAH E-COMMERCE (Theory of Planned Behavior). Jurnal Doktor Manajemen, I(01), 1-9.

Sun, H., \& Zhang, P. (2006). The Role of Moderating Factors in User Technology Acceptance. International Journal of Human-Computer Studies, 64(2), 53-78. https://doi.org/10.1016/j.ijhcs.2005.04.013

Venkatesh, V., \& Davis, F. D. (2000). A Theoretical Extension of the Technology Acceptance Model: Four Longitudinal Field Studies. Management Science, 46(2), 186-204. https://doi.org/10.1287/mnsc.46.2.186.11926

Ventre, I., \& Kolbe, D. (2020). The Impact of Perceived Usefulness of Online Reviews, Trust and Perceived Risk on Online Purchase Intention in Emerging Markets: A Mexican Perspective. Journal of International Consumer Marketing, 32(4), 287-299. https://doi.org/10.1080/08961530.2020.1712293

Wu, I. L., Chiu, M. L., \& Chen, K. W. (2020). Defining the determinants of online impulse buying through a shopping process of integrating perceived risk, expectation-confirmation model, and flow theory issues. International Journal of Information Management, 52(May 2019), 102099. https://doi.org/10.1016/j.ijinfomgt.2020.102099 
C 2022 by the authors; licensee Growing Science, Canada. This is an open access article distributed under the terms and conditions of the Creative Commons Attribution (CC-BY) license (http://creativecommons.org/licenses/by/4.0/). 